\title{
50 Years of Lithium Treatment of Bipolar Disorder: Taking on New Challenges
}

It is 50 years since John Cade published his first experiences with lithium treatment in the Medical Journal of Australia. Fortunately, the editors of the journal did not demand an extremely high scientific standard for work to be published at that time. With the present-day requests of most reviewed scientific journals, this work, that reported on the effect of lithium on guinea pigs and in an uncontrolled series of 6 patients, would never have been published. Through the discovery of lithium, research on bipolar disorder, and its therapy, made a huge advance. After some decades, however, it fell again into an increasing lethargy, under the incorrect assumption that lithium could represent a panacea. Today, however, we know that lithium cannot be the only tool to battle the increase in the complexity of the illness and possibly also its severity.

In the spirit of Cade and his contemporaries, we therefore held the First Symposium of the Munich \& Freiburg Stanley Foundation alliance 'Bipolar Illnesses - New Ways of Treatment' not only to critically question traditional treatment concepts, but simultaneously to exchange first experiences with new, partly still experimental, treatment possibilities and research strategies.
Completely in this sense of entering new grounds was also the actual occasion of the symposium, the presentation of the Glaxo-Wellcome award for the support of young researchers in the area of bipolar disorder.

Our thanks go to Glaxo-Wellcome company that has donated this innovative price and has long supported the exploration of new therapy possibilities in bipolar disorders.

The scientific sessions, including the poster session of the symposium, turned out to be so interesting and fruitful for the field of bipolar disorder research that we decided to give a larger audience access to the proceedings. Therefore, a scientific board selected the most inspiring poster presentations to be published as short reports together with the two main lectures of Greil and Nolen. As the result, we hope that the present issue of Neuropsychobiology will be as inspiring to the readers as the symposium was for the participants.

Prof. Dr. Dr. Jörg Walden Dr. Heinz Grunze

\begin{tabular}{ll}
\hline KARGER & ( ) 2000 S. Karger AG, Basel \\
0302-282X/00/0425-0001\$17.50/0 \\
$\begin{array}{l}\text { Fax +4161306 1234 } \\
\begin{array}{l}\text { E-Mail karger@karger.ch } \\
\text { www.karger.com }\end{array}\end{array}$ & $\begin{array}{l}\text { Accessible online at: } \\
\text { www.karger.com/journals/nps }\end{array}$
\end{tabular}

